\title{
DISTRIBUTION PATTERNS AND HABITATS OF ENDEMIC VASCULAR PLANTS IN THE POLISH CARPATHIANS
}

\author{
HALina PięKOŚ-MiRKowA ${ }^{1}$, ZBIGNIEW MIREK $^{2}$ \\ ${ }^{1}$ Institute of Nature Conservation, Polish Academy of Sciences \\ Al. Mickiewicza 33, 31-120 Kraków, Poland \\ e-mail:mirkowa@iop.krakow.pl, \\ ${ }^{2}$ W. Szafer Institute of Botany, Polish Academy of Sciences \\ Lubicz 46, 31-512 Kraków, Poland \\ e-mail: z.mirek@botany.pl
}

(Received: July 16, 2009. Accepted: August 6, 2009)

\begin{abstract}
The paper deals with the richness and diversity of endemic and subendemic taxa in the Polish Carpathians. Based on critical studies in the literature and the authors' unpublished materials collected in the field, the distribution patterns of endemic species are analysed and discussed. The participation of endemics in the flora of single Carpathian ranges is assessed and analysed. The importance of the Tatra Mts as a centre of endemism is stressed. The frequency and altitudinal ranges of endemic taxa are characterized and their syntaxonomical spectrum is presented.
\end{abstract}

KEY WORDS: vascular plants, endemic and subendemic taxa, distribution patterns, habitats, Polish Carpathians.

\section{INTRODUCTION}

Due to their limited distribution, endemic species are an especially important floristic element, contributing to the identity of a given flora. For this reason they play an important role in biodiversity conservation. Their number, age and distribution are crucial to understanding the history of the flora of a given area. In general, mountains are especially rich in endemics. This is true also for Central Europe, including Poland, where most of the endemic taxa are concentrated in the Carpathians (Fig. 1).

From the Polish Carpathians, covering only ca $6 \%$ of the whole country, 111 endemic and subendemic vascular plant taxa (species and subspecies) have been reported (Piękoś-Mirkowa and Mirek 2003). Some of them are believed to be paleoendemics originating from the late Tertiary. The lack of endemic species in the prevailing part of the Polish lowlands is attributable to the Pleistocene glaciations, which destroyed the old flora occurring earlier in this part of Europe.

Here we present the results of studies on richness and distribution patterns of endemic taxa in the Polish Carpathians, and characterize their altitudinal distribution and habitats.

\section{MATERIAL AND METHODS}

All 111 taxa regarded as Carpathian endemic or subendemic ones occurring in the Polish Carpathians are characterized and analysed. A previous paper includes a list of them (Piękoś-Mirkowa and Mirek 2003); however additional studies and new findings have required updating of the list. A few controversial or doubtful taxa regarded as endemic up to now, such as Alchemilla pungentiflora (Plocek 1992), Hylotelephium argutum and Linum extraaxillare (Kliment 1999), were removed from the list. Alchemilla tatricola Pawł. was taken off the list as it appears to be conspecific with A. subcrenata (Kurtto et al. 2007). Two taxa which apparently are endemic to the area have been added to the list of Carpathian endemics: Delphinium elatum subsp. nacladense (Mitka and Nowosad 2002; Mitka et al. 2008) and Euphrasia exaristata (Staszkiewicz 2008). Three species (Alchemilla ladislai, A. versipiloides and A. zmudae) of which the endemic status was doubtful were confirmed (Plocek 1992; Kurtto et al. 2007).

Maps and diagrams showing the occurrence of endemic and subendemic taxa in the Polish Carpathians were drawn based on data from local "Floras" of single Carpathian ranges (e.g., Białecka 1982; Grodzińska 1968, 1976; Grodziń- 


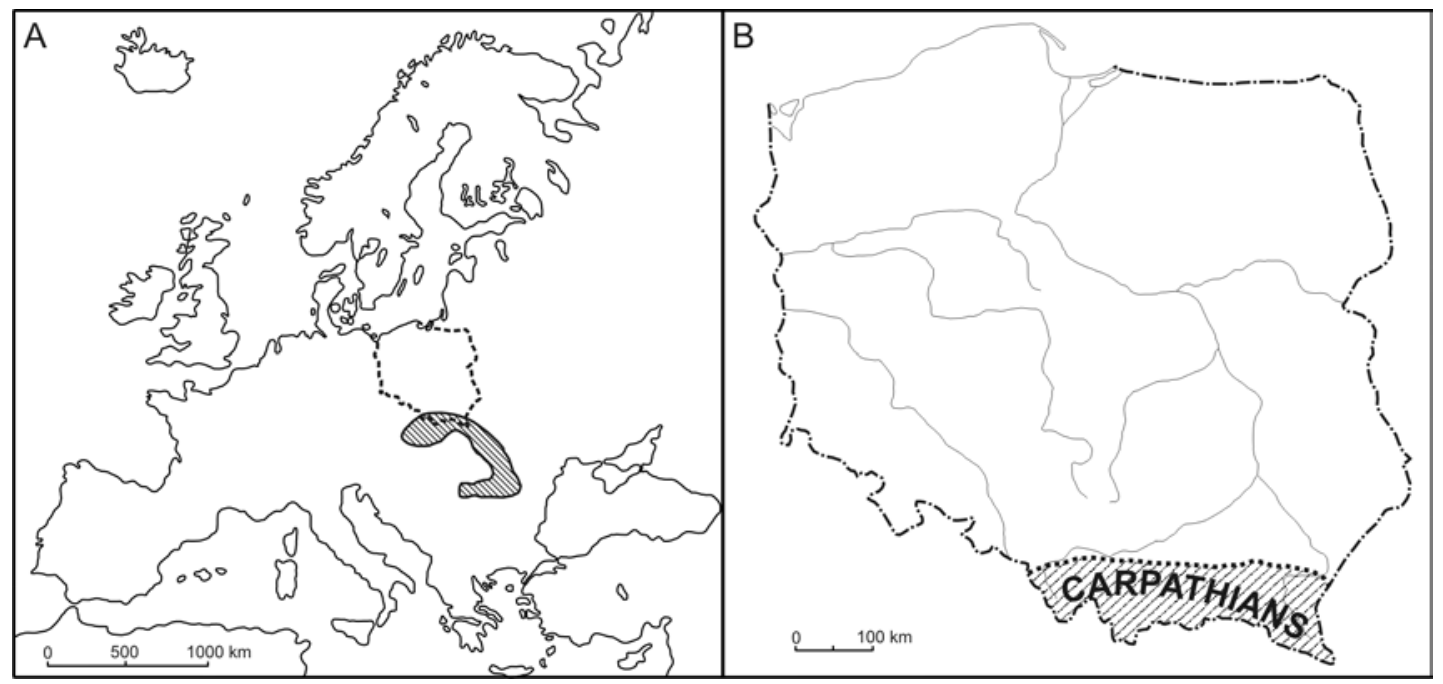

Fig. 1. Location of the Carpathians in Europe (A). Polish Carpathians - area studied (B).

ska and Pancer-Kotejowa 1960; Guzikowa 1977; Jasiewicz 1965; Kornaś 1957; Kotońska 1991; Kotula 1889-1890; Mirek 1993; Oklejewicz 1993; Pacyna 2004; Pawłowski 1925, 1956; Pelc 1967; Stuchlikowa and Stuchlik 1962; Towpasz 1975, 1987; Zając 1989; Zapałowicz 1880; Zarzycki 1981; Zemanek 1981, 1989; Zemanek and Winnicki 1999). Besides the "Floras", a great number of floristic papers and authors' unpublished materials have been incorporated. The definition of endemic species follows an earlier paper (Piękoś-Mirkowa and Mirek 2003). With a few exceptions, the nomenclature of taxa follows Mirek et al. (2002).

\section{MAIN CHARACTERISTICS OF THE STUDY AREA}

The Polish Carpathians (Fig. 1) form the northernmost part of the whole range, spanning ca $330 \mathrm{~km}$ in length and up to $90 \mathrm{~km}$ in width. They cover $19600 \mathrm{~km}^{2}$, with $87 \%$ belonging to the Western Carpathians and only $13 \%$ to the Eastern Carpathians (Warszyńska 1995). In terms of geology, relief, landscape and plant cover, three geobotanical districts have been distinguished within the Western Carpathians (Pawłowski 1972): the Tatra Mts, Pieniny Mts and Beskidy Mts (with the adjacent Carpathian foothills). The Eastern Carpathians are represented in Poland only by the Bieszczady Mts and Przemyśl foothills.

The Tatras, covering only $220 \mathrm{~km}^{2}$, built of crystalline and sedimentary rocks, are the highest mountain massif in the whole Carpathian range, with typical alpine landscape and rich glacial relief. The highest summit of the Polish Tatra Mts, Mt Rysy, reaches 2499 m a.s.l. The Pieniny Mts form a very small rocky massif built of Mesozoic limestone, with the highest point at $1052 \mathrm{~m}$ a.s.1. The Beskidy Mts are medium-altitude mountains with elevation up to 1725 $\mathrm{m}$ a.s.1. (Mt Babia Góra) in the Western Beskidy Mts and to $1346 \mathrm{~m}$ a.s.l. in Bieszczady Mts (the Eastern Beskidy Mts). They include several mountain ranges built mainly of flysh (Tertiary sedimentary bedrock consisting of alternate layers of sandstone and claystone). Their monotonous relief and landscape result in monotonous flora as well. The Carpathian foothills, where the submontane belt prevails, cover the lowest elevations between 250 and 550 (650) $m$ a.s.l. The natural environment of this belt has been significantly transformed and degraded by various forms of anthropopression.

Substantial differentiation of climatic conditions along the altitudinal gradient creates well-defined vegetation belts. Six vegetation belts can be distinguished in the Carpathians (Pawłowski 1972): submontane, lower montane, upper montane, subalpine (dwarf pine), alpine and subnival. In the Carpathians the subnival belt is found only in the Tatras.

Despite its small area, the flora of the Polish Carpathians is relatively rich, comprising ca 2200 vascular plant species, including both native taxa and established aliens (Mirek and Piękoś-Mirkowa 2008). It includes ca $74 \%$ of the total flora of the country, and more than 450 species are represented by the mountain element.

\section{RESULTS AND DISCUSSION}

Progress in taxonomic and chorological studies has brought changes in the number of endemic and subendemic taxa, their listing, and their affiliation as Pan-Carpathian, West or East Carpathian endemics. Presently it is known that 111 endemic vascular plant taxa occur in the Polish Carpathians. They include Pan-Carpathian, West, East or East and South Carpathian endemic and subendemic taxa, as well as taxa endemic to single mountain ranges: the Tatras, Pieniny Mts and Babia Góra massif. The full list includes 49 well-defined species, 27 microspecies of the genus Alchemilla, and 35 distinct subspecies.

\section{Frequency}

Most of the endemics and subendemics occurring in the Polish Carpathians are rare or very rare taxa; some of them are known from single stations only. Examples are Delphinium elatum subsp. nacladense, Euphrasia exaristata, and Taraxacum pieninicum, each noted from single stations, Pulsatilla slavica (two stations) and Pyrola carpatica (three stations). Others, such as Poa babiogorensis and Erysimum pieninicum (Fig. 2) and a dozen species of the genus Alchemilla, have no more than ten stations concentrated in a small area. Among the Carpathian endemics is one 


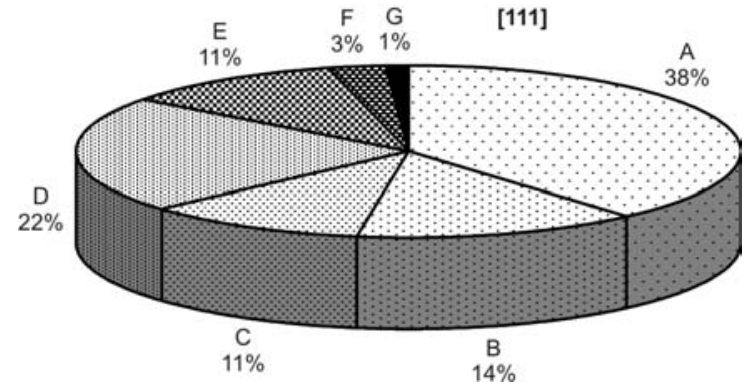

Fig. 2. Frequency of endemic and subendemic taxa in the Polish Carpathians. A - very rare; $\mathrm{B}$ - rare; $\mathrm{C}$ - fairly rare; D - fairly frequent; $\mathrm{E}$ - frequent; $\mathrm{F}$ - common; $\mathrm{G}$ - extinct.

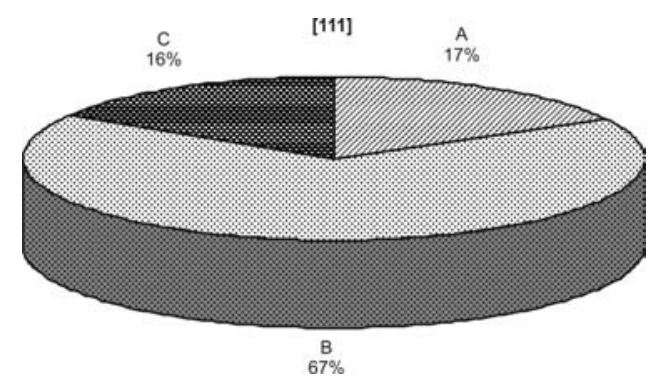

Fig. 3. Proportion of mountain multizonal (A), high mountain (B), and montane taxa $(\mathrm{C})$ in the group of endemics and subendemics occurring in the Polish Carpathians.

extinct paleoendemic species, Dianthus nitidus. It was reported in the 19th century from the Pieniny Mts (Zarzycki 1981). Rare endemic taxa are usually limited to only one mountain range, as exemplified by the taxa mentioned above. Some endemic species, though limited to only one range in the Polish Carpathians, are frequent or very frequent. Examples include Festuca tatrae, Leontodon pseudotaraxaci, Leucanthemopsis tatrae and Ranunculus pseudomontanus, which occur at numerous localities in the Tatras. Only a few endemic and subendemic taxa are widely distributed in the entire Polish Carpathians (e.g. Dentaria glandulosa, Symphytum cordatum, Leucanthemum waldsteinii). Others are common in several ranges, such as Campanula polymorpha and Crocus scepusiensis. The latter, occurring in seminatural pastured grasslands and mown meadows, has been spread by human activities.

\section{Altitudinal ranges and distribution}

As concerns vertical distribution, most of endemics and subendemics in the Polish Carpathians represent the highmountain element (Fig. 3). This group comprises 74 taxa (67\%) of all 111 endemic taxa known from the Polish Carpathians. The multizonal and montane groups are evidently less numerous, with $18(16 \%)$ and $19(17 \%)$ taxa, respectively. The proportions of endemic and subendemic taxa representing these three groups change along the altitudinal gradient (Fig. 4). Most of endemic and subendemic taxa in the Polish Carpathians occur between 1400 and 2000 $\mathrm{m}$ a.s.l. (Fig. 5). Their participation in the total flora of particular vegetational belts increases with altitude, reaching about $12 \%$ in the highest (subnival) belt (Piękoś-Mirkowa et al. 1996).

The number of endemic and subendemic taxa in various Carpathian ranges varies significantly. Most of them concentrate in the Tatra Mts (Figs 6 and 7). There occur 90 taxa $(81.8 \%$ of the total number of endemics and subendemics
A

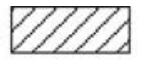
B
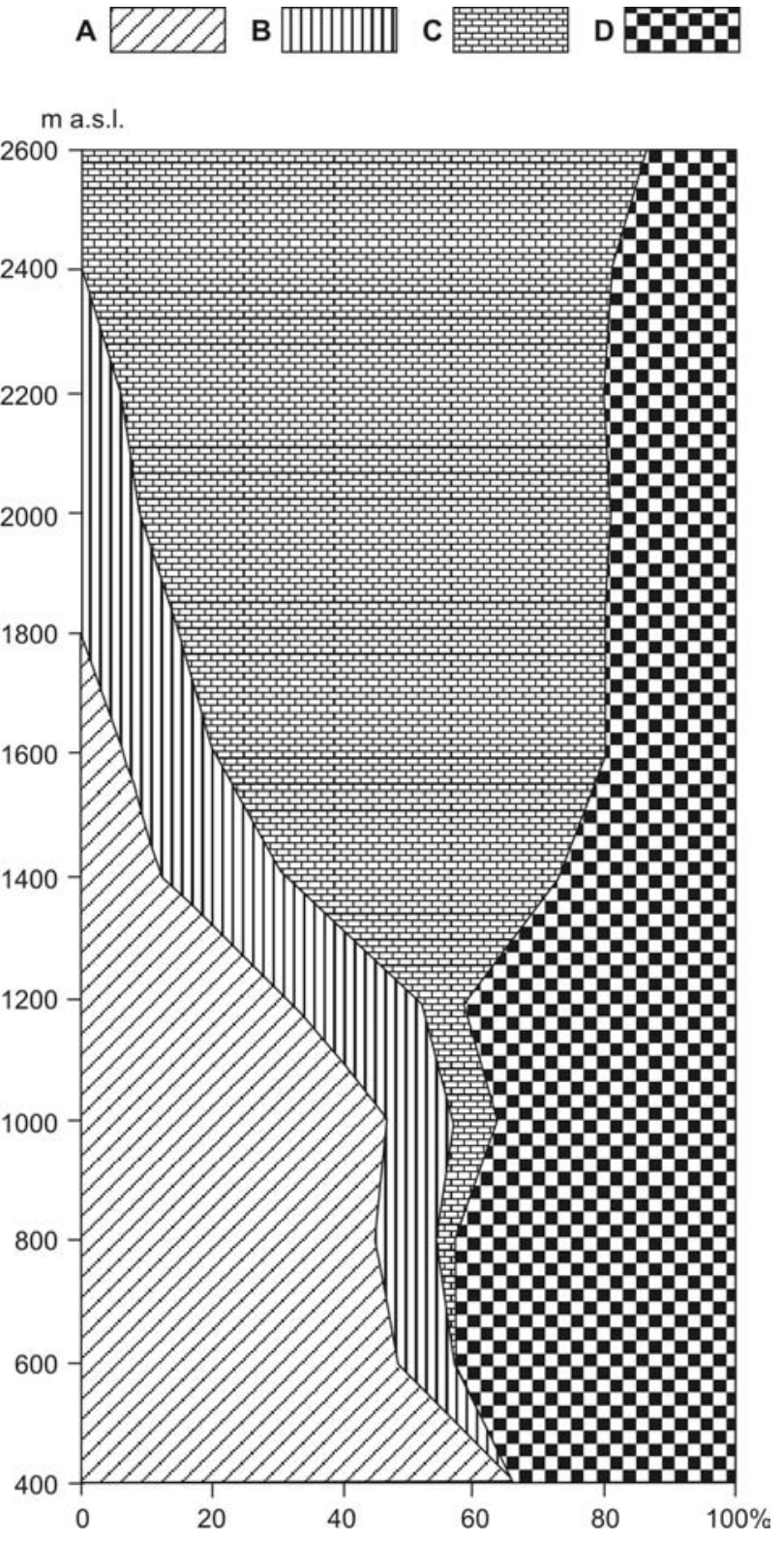

Fig. 4. Proportion of A - montane; B - subalpine; C - alpine; D - mountain multizonal endemic taxa at various altitudes in the Polish Carpathians.

known from the Polish Carpathians); 62 of them are known in Poland only from this area (e.g. Cochlearia tatrae - Fig. 8A). This shows the significance of the Tatra Mts as a centre of endemism. Diversity of endemic species is associated with the area's geological, relief, soil, climate and habitat diversity, as well as history of the area (Mirek and PiękośMirkowa 1992a, b). Though small in area and low in elevation, the Pieniny Mts are a second important centre of endemism within the Polish Western Carpathians, harbouring 19 endemic and subendemic taxa. Two of them, Taraxacum pieninicum and Erysimum pieninicum (Fig. 8B), are known only from this range. The Beskidy Mts are much poorer in endemics, with no more than 15 taxa. Mt Babia Góra, the highest massif within the Western Beskidy Mts, is the only exception. It supports 18 taxa, of which Poa babiogorensis is regarded as endemic to this massif (Fig. 8C). Two others, Alchemilla babiogorensis and A. bogumilii, previously regarded as endemic to Mt Babia Góra, appear to have a wider distribution in the Carpathians (Plocek 1992; Volgin 
m a.s.l.

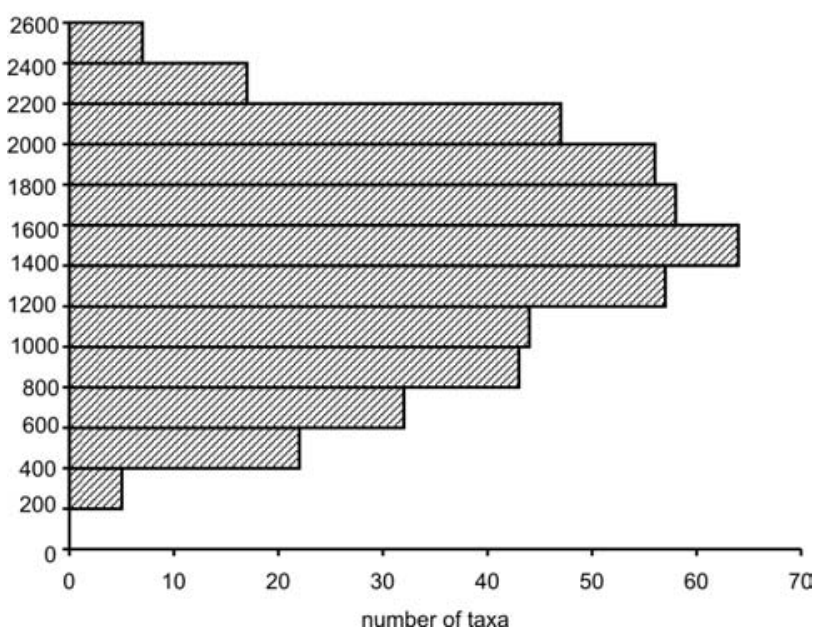

Fig. 5. Total number of endemics and subendemics in various altitudinal belts in the Polish Carpathians.

and Sychak 1989a, b; Stoyko and Tasenkevich 1993). Also Bieszczady Mts, the only higher range in the Eastern Carpathian Beskidy Mts are relatively rich, with 22 East- and
PanCarpathian endemic taxa found (e.g. Melampyrum saxosum - Fig. 8D); but with no local endemics.

At least eight Carpathian taxa are so far recognized as local stenochoric endemics of the Polish flora, not present elsewhere: Taraxacum pieninicum, T. pawtowskii, Erysimum pieninicum, Alchemilla calviflora, A. jasiewiczii, A. tacikii, A. versipiloides and $A$. zmudae. However small changes in this group are not excluded and further investigations can reveal wider distribution of some taxa. It already happened in respect to Alchemilla babiogorensis and A. bogumilii, previously regarded as endemic to Babia Góra massif. They appeared to have a wider distribution in the Carpathians (Plocek 1992; Volgin and Sychak 1989a, b; Stoyko and Tasenkevich 1993). All the other West-, East-, and PanCarpathian endemic species occurring in Poland (e.g. Soldanella carpatica and Campanula serrata - Figs 8E and F) have broader distribution in the Carpathians, and exceed country border. They represent mesochoric or eurychoric endemics (Mirek and Piękoś-Mirkowa 2009 (in press)).

\section{Habitats}

The endemic and subendemic taxa occurring in the Polish Carpathians represent a broad spectrum of habitats

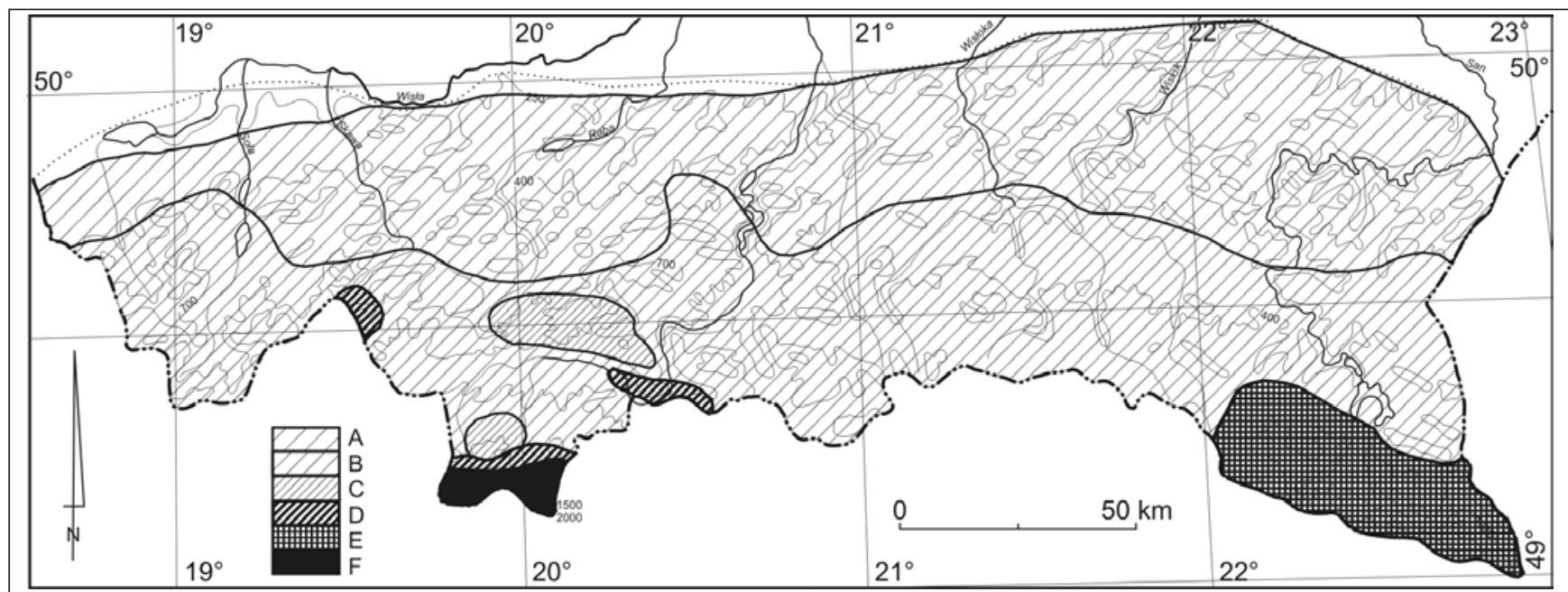

Fig. 6. Richness of endemic and subendemic taxa in the territory of the Polish Carpathians (simplified and generalized). A - 1-5 species; B - 6-10 species; C - 11-15 species; D - 16-20 species; E - 21-25; F - >25 species.

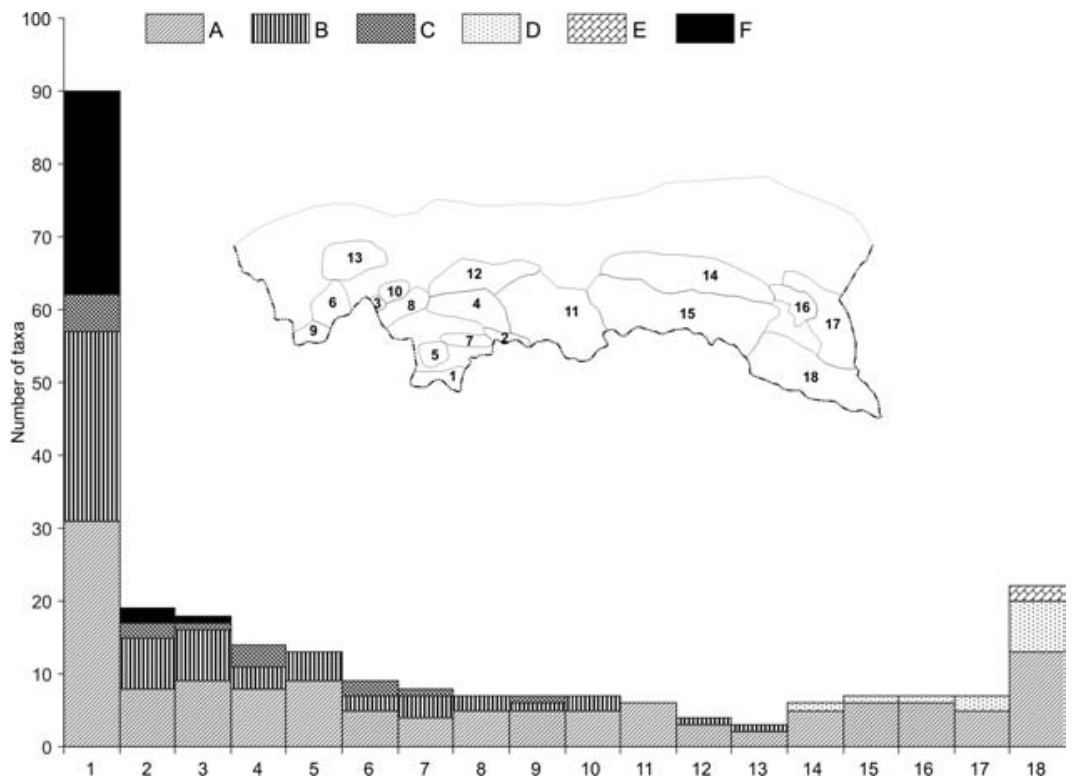

Fig. 7. Numbers of endemic and subendemic taxa occurring in particular ranges of the Polish Carpathians (in respect to main geobotanical units). A - Pan-Carpathian; B - West Carpathian; C - West and East Carpathian; D - East Carpathian; E - East and South Carpathian; F - taxa endemic to single ranges. Mountain ranges and their locations on the map: 1 - Tatras; 2 - Pieniny Mts; 3 - Mt Babia Góra; 4 - Gorce Mts; 5 - Wzniesienie Gubałowskie; 6 - Mt Pilsko; 7 - Pas Skalicowy; 8 - Działy Orawskie; 9 - Wielka Racza range; 10 - Mt Polica; 11 - Beskid Sadecki range; 12 - Beskid Wyspowy range; 13- Beskid Mały range; 14 - Doły JasielskoSanockie; 15 - Beskid Niski range; 16 Góry Słonne Mts; 17 - Bieszczady Niskie and Otryt ranges; 18 - Bieszczady Mts. 

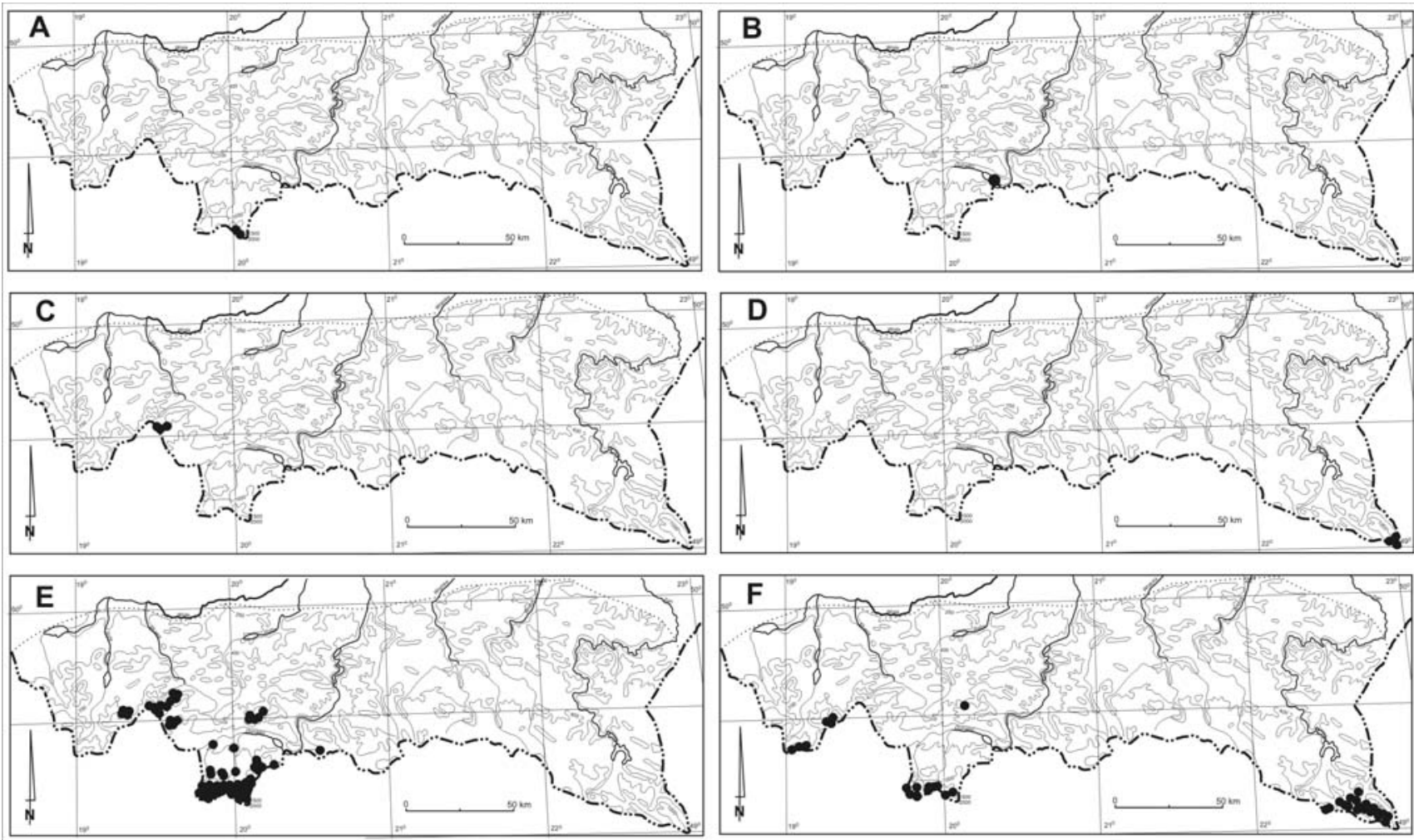

Fig. 8. Distribution of selected endemic taxa in the Polish Carpathians. A - Cochlearia tatrae Borbás - Tatra endemic; B - Erysimum pieninicum (Zapal.) Pawł. - endemic to Pieniny Mts; C - Poa babiogorensis Bernátová, Májovský et Obuch - endemic to Mt Babia Góra; D - Melampyrum saxosum Baumg. - East Carpathian endemic; E - Soldanella carpatica Vierh. - West Carpathian endemic; F - Campanula serrata (Kit.) Hendrych subsp. serrata - Pan-Carpathian endemic.

(Fig. 9). The largest group, comprising ca $27 \%$ of the taxa, is associated with high-mountain grasslands, especially those occurring on calcareous rock, and representing the class Seslerietea variae. A fair number of endemics and subendemics $(26 \%)$ can be found as components of scree, gravel, rock crevice and snow patch vegetation both on calcareous and silicious substrata (classes Thlaspietea rotundifolii, Salicetea herbaceae and Asplenietea rupestria). Most of the taxa representing these groups are restricted to the Tatra Mts. There is also a significant number (ca 20\%) of taxa occurring in tall-herb and tall-grass vegetation (representatives of the class Betulo-Adenostyletea). Only seven endemic and subendemic taxa (ca 6\%) are associated with woodlands (classes Querco-Fagetea and Vaccinio-Piceetea).

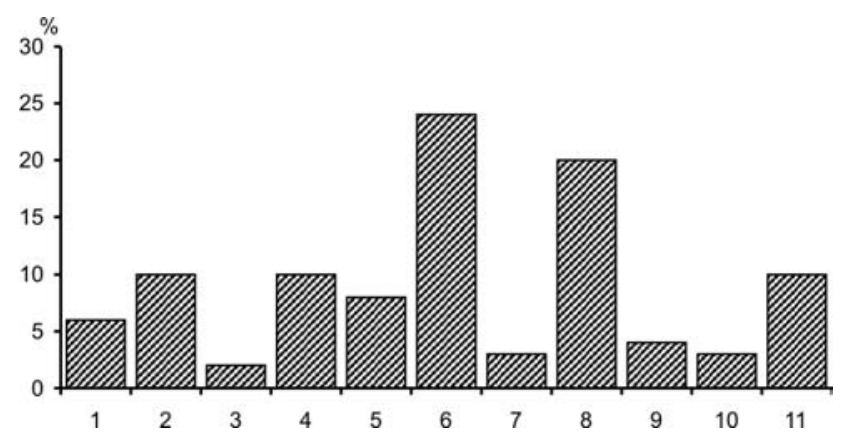

Fig. 9. Syntaxonomic spectrum of endemic and subendemic taxa occurring in the Polish Carpathians. Phytosociological units (classes): 1 Asplenietea rupestria; 2 - Thlaspietea rotundifolii; 3 - Montio-Cardaminetea; 4 - Salicetea herbaceae; 5 - Molinio-Arrhenatheretea; 6 - Seslerietea variae; 7 - Juncetea trifidi; 8 - Betulo-Adenostyletea; 9 - Querco-Fagetea; 10 - Vaccinio-Piceetea; 11 - others.

\section{ACKNOWLEDGEMENTS}

We are grateful to Hanna Kuciel for preparing the drawings. The study was funded by the Polish State Committee for Scientific Research (KBN Grant No. 2P04G06028).

\section{LITERATURE CITED}

BIAŁECKA K. 1982. Rośliny naczyniowe Grupy Pilska w Beskidzie Żywieckim. Zesz. Nauk. UJ, Prace Bot. 10: 1-149. (in Polish with English summary)

GRODZIŃSKA K. 1968. Rośliny naczyniowe Pasma Bukowicy (Beskid Niski). Fragm. Flor. Geobot. 14: 3-82. (in Polish with English summary)

GRODZIŃSKA K. 1976. Rośliny naczyniowe Skalic Nowotarskich i Spiskich (Pieniński Pas Skałkowy). Fragm. Flor. Geobot. 22: 43-127. (in Polish with English summary)

GRODZIŃSKA K., PANCER-KOTEJOWA E. 1960. Flora Wzniesienia Gubałowskiego. Monogr. Bot. 11: 1-196. (in Polish with English summary)

GUZIKOWA M. 1977. Rośliny naczyniowe Działów Orawskich i Bramy Sieniawskiej (południowo-wschodnia część Beskidu Żywieckiego). Monogr. Bot. 53: 1-267. (in Polish with English summary)

JASIEWICZ A. 1965. Rośliny naczyniowe Bieszczadów Zachodnich. Monogr. Bot. 22: 1-340. (in Polish with English summary)

KLIMENT J. 1999. Komentovaný prehl'ad vyššich rastlin flóry Slovenska, uvádzaných v literatúre ako endemické taxóny. Bull. Slov. Botan. Spol., 21(4): 200-434. (in Slovak with English summary)

KORNAŚ J. 1957. Rośliny naczyniowe Gorców. (Plantes vasculaires des Gorce. Monogr. Bot. 5: 1-259. (in Polish with French summary) 
KOTOŃSKA B. 1991. Rośliny naczyniowe Beskidu Małego (polskie Karpaty Zachodnie). Zesz. Nauk. UJ, Prace Bot. 23: 1-199. (in Polish with English summary)

KOTULA B. 1889-1890. Rozmieszczenie roślin naczyniowych w Tatrach. Nakł. Wydz. Mat.-Przyr. AU, Kraków, pp. 512. (in Polish)

KURTTO A. FRÖHNER S. E., LAMPINEN R. (eds). 2007. Atlas Florae Europaea. Distribution of Vascular Plants in Europe. 14. Rosaceae (Alchemilla and Aphanes). The Committee for Mapping the Flora of Europe and Societas Biologica Fennica Vanamo. Helsinki.

MIREK Z. 1993. Rośliny naczyniowe. In: Mirek Z., Piękoś-Mirkowa H. (eds), Przyroda Kotliny Zakopiańskiej. Poznanie, Przemiany, zagrożenia i ochrona. Tatry i Podtatrze, 2: 117-170. (in Polish)

MIREK Z., PIĘKOŚ-MIRKOWA H. 1992a. Plant cover of the Western Carpathians (S. Poland). Veröffentlichungen des Geobotanischen Institutes der Eidg. Tech. Hochschule, Stiftung Rübel, Zürich 107: 116-150.

MIREK Z., PIĘKOŚ-MIRKOWA H. 1992b. Plant cover of the Polish Tatra Mts. (S. Poland). Veröffentlichungen des Geobotanischen Institutes der Eidg. Tech. Hochschule, Stiftung Rübel, Zürich 107: 177-199.

MIREK Z., PIĘKOŚ-MIRKOWA H. (eds). 2008. Czerwona Księga Karpat Polskich. Rośliny naczyniowe. Instytut Botaniki im. W. Szafera PAN, Kraków, pp. 615. (in Polish with English summary)

MIREK Z., PIĘKOŚ-MIRKOWA H. 2009. Phytogeographic aspects of endemism in Poland. Polish Botanical Studies. (in press)

MIREK Z., PIĘKOŚ-MIRKOWA H., ZAJĄC A., ZAJĄC M. 2002. Flowering plants and pteridophytes of Poland. A CheckList. W. Szafer Institute of Botany, Polish Academy of Sciences, Kraków, pp. 457.

MITKA J., NOWOSAD J. 2002. Rodzaj Delphinium L. (Ranunculaceae) w Polsce - wstępne wyniki badań. (The genus Delphinium L. in Poland - preliminary results). Roczn. Bieszczadzkie 10: 233-252. (in Polish with English summary)

MITKA J., ZEMANEK B., WINNICKI T., MIREK Z. 2008. Ostróżka wyniosła wschodniokarpacka Delphinium elatum subsp. nacladense (Zapał.) Holub. In: Czerwona Księga Karpat Polskich. Rośliny naczyniowe. Mirek Z., Piękoś-Mirkowa H. (eds). Instytut Botaniki im. W. Szafera PAN, Kraków, pp. 84-85. (in Polish with English summary)

OKLEJEWICZ K. 1993. Flora Dołów Jasielsko-Sanockich. Zesz. Nauk. Uniw. Jagiell., Prace Bot. 26: 1-165. (in Polish with English summary)

PACYNA A. 2004. Rośliny naczyniowe wschodniej części Pogórza Wielickiego i przylegającej części Beskidów (Karpaty Zachodnie). Prace Botaniczne 38: 1-367. (in Polish with English summary)

PAWŁOWSKI B. 1925. Geobotaniczne stosunki Sądecczyzny. Prace Monogr. Kom. Fizjogr. PAU 1: 1-342. (in Polish)

PAWŁOWSKI B. 1956. Flora Tatr. Rośliny naczyniowe. Vol. 1. PWN, Warszawa. (in Polish with Latin summary)

PAWŁOWSKI B. 1972. Szata roślinna gór polskich. In: Szafer W., Zarzycki K. (eds), Szata roślinna Polski. 2: 189-252, PWN, Warszawa. (in Polish)

PELC S. 1967. Rośliny naczyniowe Pogórza Cieszyńskiego. Roczn. Nauk.-Dydakt. WSP Kraków 28: 109-208. (in Polish)
PIĘKOŚ-MIRKOWA H., MIREK Z. 2003. Endemic taxa of vascular plants in the Polish Carpathians. Acta Soc. Bot. Pol. 72(3): 235-242.

PIĘKOŚ-MIRKOWA H., MIREK Z., MIECHÓWKA A. 1996. Endemic Vascular Plants in the Polish Tatra Mts. Distribution and Ecology. Pol. Bot. Stud., 12: 1-107.

PLOCEK A. 1992. Alchemilla L. Alchemilka. In: Flóra Slovenska. Bertová L. (ed.). Veda, 4/3: 250-373, Vyd. SAV, Bratislava. (in Slovak)

STASZKIEWICZ J. 2008. Świetlik bezostny Euphrasia exaristata Smejkal. In: Czerwona Księga Karpat Polskich. Rośliny naczyniowe. (Red data book of Polish Carpathians. Flowering plants). Mirek Z., Piękoś-Mirkowa H. (eds), Instytut Botaniki im. W. Szafera PAN, Kraków, pp. 298-299. (in Polish with English summary)

STOYKO S.M., TASENKEVICH L. 1993. Some aspects of endemism in the Ukrainian Carpathians. Fragm. Flor. Geobot. Suppl. 2(1): 343-353.

STUCHLIKOWA B., STUCHLIK L. 1962. Geobotaniczna charakterystyka pasma Policy w Karpatach Zachodnich. Fragm. Flor. Geobot. 8: 229-396. (in Polish with English summary)

TOWPASZ K. 1975. Rośliny naczyniowe południowo-wschodniej części Beskidu Wyspowego. Cz. II. Monogr. Bot. 48: 1145. (in Polish with English summary)

TOWPASZ K. 1987. Rośliny naczyniowe Pogórza Strzyżowskiego Zesz. Nauk. UJ, Prace bot. 16: 1-157. (in Polish with English summary)

VOLGIN S.A., SYCHAK N.H. 1989a. Manzhetki Alchemilla L., (Rosaceae) Ukrainkikh Karpat. I. Sektsya Alchemilla podsektsya Calycinae (Buser) Camus (Alchemilla L. (Rosaceae) of the Ukrainian Carpathians. 1 sect. Alchemilla subsect. Calycinane (Buser) Camus). Biul. Moscow. Obshch. Ispyt. Prir. Biol. Ser. 94(2): 71-79.

VOLGIN S.A., SYCHAK N.H. 1989b. Manzhetki Alchemilla L., (Rosaceae) Ukrainkikh Karpat. II. Sektsya Alchemilla podsektsya Euvulgare Camus (Rjady Glabrae Pawł. i Subglabrae Pawł.) (Alchemilla L. (Rosaceae) of the Ukrainian Carpathians. 11 sect. Alchemilla subsect. Euvulgare Camus (Series Glabrae Pawł. i Subglabrae Pawł.)). Biul. Moscow. Obshch. Ispyt. Prir. Biol. Ser. 94(6): 86-94.

WARSZYŃSKA J. (ed.). 1995. Karpaty polskie - przyroda, człowiek i jego działalność. Uniwersytet Jagielloński, Kraków. (in Polish with English summary)

ZAJĄC M. 1989. Flora południowej części Kotliny Oświęcimskiej i Pogórza Śląskiego. Zesz. Nauk. UJ, Prace Bot. 19:1-199. (in Polish with English summary)

ZAPAŁOWICZ H. 1880. Roślinność Babiej Góry pod względem geograficzno-botanicznym. Spraw. Komis. Fizjogr. AU 14: 79-251 (in Polish).

ZARZYCKI K. 1981. Rośliny naczyniowe Pienin. Rozmieszczenie i warunki występowania. PWN, Inst. Botaniki PAN, Kraków-Warszawa. (in Polish with English summary)

ZEMANEK B. 1981. Rośliny naczyniowe Gór Słonnych (polskie Karpaty Wschodnie). Zesz. Nauk. UJ, Prace Bot. 8: 35-124. (in Polish with English summary)

ZEMANEK B. 1989. Rośliny naczyniowe Bieszczadów Niskich i Otrytu (polskie Karpaty Wschodnie). Zesz. Nauk. UJ, Prace Bot. 20: 1-185. (in Polish with English summary)

ZEMANEK B., WINNICKI T. 1999. Rośliny naczyniowe Bieszczadzkiego Parku Narodowego. Monogr. Bieszczadzkie 3: 1-249. (in Polish with English summary) 